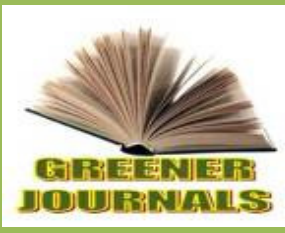

\title{
Seasonal Variation in Length-Weight Relationship and Condition Factor of Five Fish Species from Kolo Creek, Niger Delta
}

\section{Enetimi Idah Seiyaboh ${ }^{1}$, Sylvester Chibueze Izah $^{1 *}$ and Blessing Chidinma Okogbue ${ }^{2}$}

${ }^{1}$ Department of Biological Science, Faculty of Science, Niger Delta University, Wilberforce Island, Bayelsa State, Nigeria

${ }^{2}$ Department of Fisheries and Aquaculture, School of Agricultural Technology, Federal Polytechnic Ekowe, Bayelsa state, Nigeria

\section{ARTICLE INFO}

Article No.: 121916216

DOI: 10.15580/GJAS.2016.11.121916216

Submitted: $19 / 12 / 2016$

Accepted: $21 / 12 / 2016$

Published: 27/12/2016

${ }^{*}$ Corresponding Author

Sylvester Chibueze Izah

E-mail: chivestizah@gmail.com

\section{Keywords:}

Condition factor, Fisheries, Lengthweigh relationship, Kolo creek
Weight-length relationship and condition factor of a fish is frequently used to evaluate the well-being of such fish in its environment. This study investigated the seasonal variation in length-weigh and condition factor of five important fish species from Kolo creek, Niger Delta region of Nigeria. The fish samples were obtained from the creek using different fishing gears with assistance of local fishermen. The length-weigh relationship and condition factor were computed following standard biometric methods. Results obtained showed that all the fish species showed negative allometric growth in both climatic regimes except Tilapia guineensis during the wet season. The condition factor ranged from 0.70 2.46 for both climatic condition. The condition factor fluctuates among the various seasons for each of the fish species. This suggests that the fish species adapt different at same environmental condition and can be influenced by seasons. 


\section{INTRODUCTION}

Kolo Creek is one of the numerous creeks in the Niger Delta. Kolo creek is found in Ogbia Local government area of Bayelsa State. The creek bifurcates from the Orashi river. Several economic activities such as oil and gas are carried out in the area. According to Inengite et al. (2012), Kolo Creek has been urbanized and industrialized due to the quest for crude oil. Kolo creek is one the oldest flow station in the region. The creek transverse through several communities in the area including Imiringi, Otuasega and Oruma etc (Inengite et al., 2010). The creek is also a nursery and breeding ground for several fish species.

Due to the activities of human in the creek, its productivity, species distribution and abundance could be altered. Fisheries is an essential source of animal protein (Ineyougha et al., 2015; Izah and Angaye, 2015). Fish has high quality nutrients and vitamins. According to Raufu et al. (2009), fish contain high quality proteins, fats, vitamins, calcium, iron and essential amino acids. Fisheries are important in national food security (Nazeef and Abubakar, 2013) in many countries that has high inland coastal water ways.

Fisheries are obtained from the wild i.e. natural stock and pond (Izah and Angaye, 2016). Fish rearing is a major source of livelihood/ employment to several families (Izah and Angaye, 2016; Amiye and Erondu, 2010). According to Amiye and Erondu (2010), fish from the wild and its products are rich food for teaming people in developing countries especially in rural area that has natural aquatic ecosystem. Fish species in the wild are being threatened and many species are endangered as such their productivity in natural water ways has reduced (Angaye et al., 2015; Amiye and Erondu, 2010).

Risk of fish species going into extinction has necessitated the packaging of the management of fisheries mainly in the tropical region to ensure sustainable conservation of biodiversity and sustainable use of the fishery resource (Amiye and Erondu, 2010). As such, several biometric indices have been used to assess condition of a fish in its ecosystem including length-weight relationship and condition factor (Abowei, 2006, 2009, 2010; Abu and Agarin, 2016; Nehemia et al., 2012; Keyombe et al., 2015; Seiyaboh et al., 2013, 2016a,b; Onimisi and Ogbe, 2015; Atama et al., 2013; Mahmood et al., 2012).

According to Abu and Agarin (2016), Length weight relationship and condition factor are important tool in fish biology studies. Length-weight relationship allows the conversion of growth-in-length equations to growth-in-weight in which a biometric model is used in the estimation of biomass from length and condition (Abu and Agarin, 2016; Kouamé et al., 2016). In the other hands, Condition factor is useful in assessing growth rate, age and feeding intensity and general wellbeing of fish (Abowei, 2006; Oribhabor et al., 2011; Abu and Agarin, 2016; Kumolu-Johnson and Ndimele, 2010;
Onimisi and Ogbe, 2015). These fish condition indices can also be used to assess life cycle of fisheries (lyabo et al., 2015) and relationship between the between biotic and abiotic factors in aquatic ecosystem (Lalrinsanga et al., 2012). Information about the weight-lenght relationship from Kolo creek is scares. Hence this study aimed at evaluating the length-weight relationship and condition factor of five important fish species from Kolo creek, Niger Delta region of Nigeria.

\subsection{MATERIALS AND METHOD}

\subsection{Study Area}

Kolo Creek is a narrow stream that bifurcates from the Orashi, in Rivers state and passes through several communities in Ogbia Local Government Area of Bayelsa State. Kolo creek is a major inland water ways emanating from a major river in the Niger Delta. The creek receives organic and chemical wastes arising from rapid industrialization cum high population, unhygienic habits (Aghoghovwia and Ohimain, 2014). Two predominant climatic conditions are observed in Kolo creek just as other locations in the Niger Delta. The climatic condition of the creek has been previously reported by Ogamba et al. (2015).

\subsection{Fish Sampling}

Fish sampling was carried out during the month of March (dry season) and September (wet season) in Kolo creek covering five communities including Kolo II, Kolo III, Elebele, Imiringi, and Otuasaga. Sampling were carried out using different fishing gears including hook, gill nets, bonga driftnets, cast nets and various types of traps and stakes. The five fish species studied were caught with the assistance of local fishermen in the area. The fishes were conveyed in thermos cool boxes to the laboratory on each sampling day. Fish specimens were identified using monograph descriptions, checklists and keys (Boseman, 1963; Reed et. al., 1967; Holden and Reed, 1972; Poll, 1974; Whyte, 1975; Jiri, 1976; Reed \& Sydenham, 1978; Otobo, 1981; Alfred Ockiya, 1983; Whitehead, 1984; Loveque et al., 1991). The total length of each fish was measured from the anterior tip of the fish to the caudal fin using the metre rule calibrated in centimeter. Fish weight was obtained after drilling water from the buccal cavity and blot drying with a dry piece of clean hand towel, weighing was done in a table top weighing balance to the nearest grams (Seiyaboh et al., 2013, 2016a,b)

\subsection{Length Weight Relationship}

The relationship between the length (L) and weight (W) of the various fish species were expressed by the exponential equation (Pauly, 1983): 
$\mathrm{W}=\mathrm{aL}^{\mathrm{b}}$

(Eqn. 1)

Where

$\mathrm{W}=$ Weight of fish in $(\mathrm{g})$

$\mathrm{L}=$ Total Lenght of fish in $(\mathrm{cm})$

$\mathrm{a}=$ Constant (intercept)

$\mathrm{b}=$ The Length exponent (Slope)

The "a" and "b" values were obtained from a linear regression of the length and weight of fish. When $b$ is equal to three (3), isometric pattern of growth occurs but when $b$ is not equal to 3 , allometric pattern of growth occurs, which may be positive if $>3$ or negative if $<3$ (Nehemia et al., 2012; Keyombes et al., 2015; Seiyaboh et al., 2016a, b). The correlation ( $r$ ) that is the degree of association between the length and weight was computed from the linear regression analysis.

\subsection{Condition Factor}

The condition factor $(K)$ of the experimental fish was estimated from the relationship:

$$
\mathrm{K}=100 \mathrm{~W} / \mathrm{L}^{3}
$$

Where;

$\mathrm{K}=$ Condition Factor

$\mathrm{W}=$ Weight of Fish $(\mathrm{g})$

$\mathrm{L}=$ Length of Fish $(\mathrm{cm})$

\subsection{Analysis of Experimental Data}

Regression and Correlation Analysis (RECA) for linear regression of length and weight of fish, Microsoft Excel (2014) for computation of means and standard deviation; Statistical Package for Social Sciences (SPSS) and FISAT (Gayando and Pauly, 1997) for descriptive statistics, length-weight relationship and condition factor of fish.

\subsection{RESULTS AND DISCUSSION}

The length-weight relationship of five fish species under study from Kolo creek for dry and wet season is presented in Table 1. The length-weight relationship "b" value in the dry season ranged from 0.546 (Synodontis ocellifer) to 2.516 (Tilapia guineensis) while in wet season the "b" value ranged from 0.761 (Polypterus senegalus) to 3.328 (Tilapia guineensis). The regression trend indicate that in the dry season, all fish species exhibit negative allometric growth pattern, with length exponent "b" value range from 0.546 (Synodontis ocellifer) to 2.516 (Tilapia ocellifer). In the wet season all fish species exhibit negative allometric growth pattern with length exponent "b" value range from 0.761 (Polypterus senegalus) to 2.817 (Synodontis ocellifer), except Tilapia guineensis which exhibit positive allometric growth pattern in the wet season with length exponent "b" value ranged 3.328 .

Length-weight regression equation, correlation coefficient $(r)$, coefficient of determination $\left(r^{2}\right)$, and significance of correlation showing the various fish species for dry and wet season is presented in Table 2. In the dry season, the correlation coefficient " $r$ " value range from0.374 (Hepssetus odoe) to 0.610 (Polypterus senengalus) while in the wet season the "r" value ranged from 0.413 (Polypterus senegalus) to 0.935 (Hepssetus Odoe). All the fish species under both climatic regimes is $<3$ apart from Tilapia guineensis during wet season. This is an indication that most fish species in Kolo creek has negative allometric pattern of growth. This trend have been variously reported in different fish species in surface water in Nigeria including 20 fish species from Ologe lagoon (Kumolu-Johnson and Ndimele, 2010), 8 fish species from River Okura (Onimisi and Ogbe, 2015), 5 fish species from Lower Usuma Reservoir in Abuja (Dan-Kishiya, 2013), Auchenoglanis occidentalis from Lake Akata (Ikongbeh et al., 2013). Negative allometric growth could be due to variation in water quality parameters (salinity, temperature, etc), maturing, age, sex and organ development. Changes in water quality parameters can be influenced by the nature of anthropogenic activities in the creek and season. 
Table 1: Length-Weight Relationship of Various Fish Species in Kolo Creek

\begin{tabular}{|c|c|c|c|c|c|c|c|c|c|c|c|c|c|c|c|}
\hline Species & Season & Tot. & $\begin{array}{l}\text { Length } \\
\text { Range }\end{array}$ & Min. & Max. & Mean士S.E & $\begin{array}{l}\text { Weight } \\
\text { Range }\end{array}$ & Min. & Max. & Mean士S.E & $a$ & $\mathrm{~b}$ & $\mathrm{R}$ & $r^{2}$ & $\begin{array}{l}\text { Growth } \\
\text { Pattern }\end{array}$ \\
\hline \multirow{2}{*}{ Hepssetus odoe } & Dry & 100 & 19.01 & 10.00 & 29.01 & $14.79 \pm 0.40$ & 128.99 & 1.01 & 130.00 & $52.49 \pm 2.38$ & 0.488 & 1.014 & 0.374 & 0.140 & NA \\
\hline & Wet & 100 & 19.50 & 10.00 & 29.50 & $17.76 \pm 0.44$ & 189.00 & 31.00 & 220.00 & $83.60 \pm 2.78$ & 0.246 & 1.336 & 0.935 & 0.874 & NA \\
\hline \multirow{2}{*}{$\begin{array}{l}\text { Tilapia } \\
\text { guineensis }\end{array}$} & Dry & 100 & 3.50 & 10.00 & 13.50 & $11.47 \pm 0.12$ & 32.90 & 21.00 & 53.90 & $33.20 \pm 1.82$ & 0.855 & 2.516 & 0.518 & 0.268 & NA \\
\hline & Wet & 100 & 4.50 & 10.00 & 14.50 & $11.59 \pm 0.09$ & 33.71 & 20.19 & 53.90 & $39.04 \pm 1.34$ & 0.506 & 3.328 & 0.655 & 0.429 & PA \\
\hline \multirow{2}{*}{$\begin{array}{l}\text { Protopterus } \\
\text { annectens }\end{array}$} & Dry & 100 & 22.50 & 12.00 & 34.50 & $22.83 \pm 0.42$ & 856.93 & 43.07 & 900.00 & $115.15 \pm 9.07$ & 0.570 & 1.065 & 0.491 & 0.241 & NA \\
\hline & Wet & 100 & 21.99 & 12.01 & 34.00 & $22.76 \pm 0.50$ & 270.00 & 30.00 & 300.00 & $103.49 \pm 6.12$ & 0.077 & 1.395 & 0.623 & 0.388 & NA \\
\hline \multirow{2}{*}{$\begin{array}{l}\text { Polypterus } \\
\text { senegalus }\end{array}$} & Dry & 100 & 18.45 & 12.05 & 30.50 & $24.93 \pm 0.40$ & 114.80 & 40.20 & 155.00 & $103.23 \pm 2.80$ & 0.496 & 1.077 & 0.610 & 0.372 & NA \\
\hline & Wet & 100 & 12.95 & 17.06 & 30.00 & $25.89 \pm 0.49$ & 106.00 & 50.50 & 156.50 & $112.12 \pm 3.68$ & 0.965 & 0.761 & 0.413 & 0.170 & NA \\
\hline \multirow{2}{*}{$\begin{array}{l}\text { Synodontis } \\
\text { ocellifer }\end{array}$} & Dry & 100 & 13.60 & 9.00 & 14.50 & $13.95 \pm 1.36$ & 50.00 & 16.00 & 66.00 & $32.62 \pm 1.43$ & 0.864 & 0.546 & 0.485 & 0.235 & NA \\
\hline & Wet & 100 & 7.00 & 9.50 & 16.50 & $12.72 \pm 0.19$ & 43.00 & 16.00 & 59.00 & $36.37 \pm 1.56$ & 0.632 & 2.817 & 0.921 & 0.848 & NA \\
\hline
\end{tabular}

Table 2: Length - Weight Regression Equation, Correlation Coefficient $(r)$, Coefficient of Determination $\left(r^{2}\right)$ and Significance of Correlation for Various Fish Species in Kolo Creek

\begin{tabular}{|c|c|c|c|c|c|}
\hline Fish Species & Season & Rearession Equation & $\mathrm{R}$ & $r^{2}$ & Sianificance of Correlation \\
\hline Hepssetus odoe & $\begin{array}{l}\text { Dry } \\
\text { Wet }\end{array}$ & $\begin{array}{l}\log W=0.488+1.014 \log \mathrm{L} \\
\log W=0.246+1.336 \mathrm{Log} L\end{array}$ & $\begin{array}{l}0.374 \\
0.935\end{array}$ & $\begin{array}{l}0.140 \\
0.874\end{array}$ & $\begin{array}{l}P<0.05 ; t=3.99, d f=99 \\
P<0.05 ; t=26.03, d f=99\end{array}$ \\
\hline Tilapia guineensis & $\begin{array}{l}\text { Dry } \\
\text { Wet }\end{array}$ & $\begin{array}{l}\log W=0.855+2.516 \log \mathrm{L} \\
\log W=0.506+3.328 \log \mathrm{L}\end{array}$ & $\begin{array}{l}0.518 \\
0.655\end{array}$ & $\begin{array}{l}0.268 \\
0.429 \\
\end{array}$ & $\begin{array}{l}P<0.05 ; t=3.92, d f=99 \\
P<0.05 ; t=8.58, d f=99\end{array}$ \\
\hline Protopterus annectens & $\begin{array}{l}\text { Dry } \\
\text { Wet }\end{array}$ & $\begin{array}{l}\log W=0.570+1.065 \log \mathrm{L} \\
\log W=0.077+1.395 \mathrm{Log} L\end{array}$ & $\begin{array}{l}0.491 \\
0.623\end{array}$ & $\begin{array}{l}0.242 \\
0.388\end{array}$ & $\begin{array}{l}P<0.05 ; t=5.58, d f=99 \\
P<0.05 ; t=7.88, d f=99\end{array}$ \\
\hline Polypterus senegalus & $\begin{array}{l}\text { Dry } \\
\text { Wet }\end{array}$ & $\begin{array}{l}\log W=0.496+1.077 \log \mathrm{L} \\
\log W=0.965+0.761 \mathrm{Log} L\end{array}$ & $\begin{array}{l}0.610 \\
0.413\end{array}$ & $\begin{array}{l}0.372 \\
0.170\end{array}$ & $\begin{array}{l}P<0.05 ; t=7.63, d f=99 \\
P<0.05 ; t=3.07, d f=99\end{array}$ \\
\hline Synodontis ocellifer & $\begin{array}{l}\text { Dry } \\
\text { Wet }\end{array}$ & $\begin{array}{l}\log W=0.864+0.546 \log L \\
\log W=0.633+2.817 \text { LogL }\end{array}$ & $\begin{array}{l}0.485 \\
0.921\end{array}$ & $\begin{array}{l}0.235 \\
0.848\end{array}$ & $\begin{array}{l}P<0.05 ; t=5.49, d f=99 \\
P<0.05 ; t=23.40, d f=99\end{array}$ \\
\hline
\end{tabular}


The condition factor of various fish species in Kolo creek showing the value for both dry and wet season is presented in Figure 1. During the dry season the mean condition factor ranged from 0.74 (Polypterus senengalus) to 2.17 (Tilapia guineensis), while in the wet season, the mean condition factor value ranged from 0.70 (Polypterus senegalus) to 2.46 (Tilapia guineensis). Jan and Ahmed (2016), De Giosa et al. (2014) reported that variation in condition factor of fish under two climatic condition (season) could be associated to low feeding intensity and degeneration of ovaries during winter (wet season) and high feeding intensity and full development of gonads during summer (dry season). The findings of this study also suggest that species have different adaptation strategies. This could be the reason why there is fluctuations in condition factor of fish species studied under the different climatic condition. The findings of this study has some similarity with the findings of other authors in different surface water bodies including Nkoro River (Abowei, 2006; 2009), New Calabar River (Abu and Agarin, 2016), river Benue (Akombo et al., 2014), Lake Akata (Ikongbeh et al., 2013), Ologe Lagoon (Kumolu-Johnson and Ndimele, 2010), Dadin Kowa Dam (Nazeef and Abubakar, 2013), Odi River (Ogamba et al., 2014), River Okura (Onimisi and Ogbe, 2015), Sangana river (Seiyaboh et al., 2016), Brass river (Seiyaboh et al., 2016), Igbedi creek (Seiyaboh et al., 2013). The variation could be due to differences in fish species, sex, age and water quality parameters. Typically surface water is frequently affected by wastes discharged into the water and/ or effect of runoff resulting from rainfall.

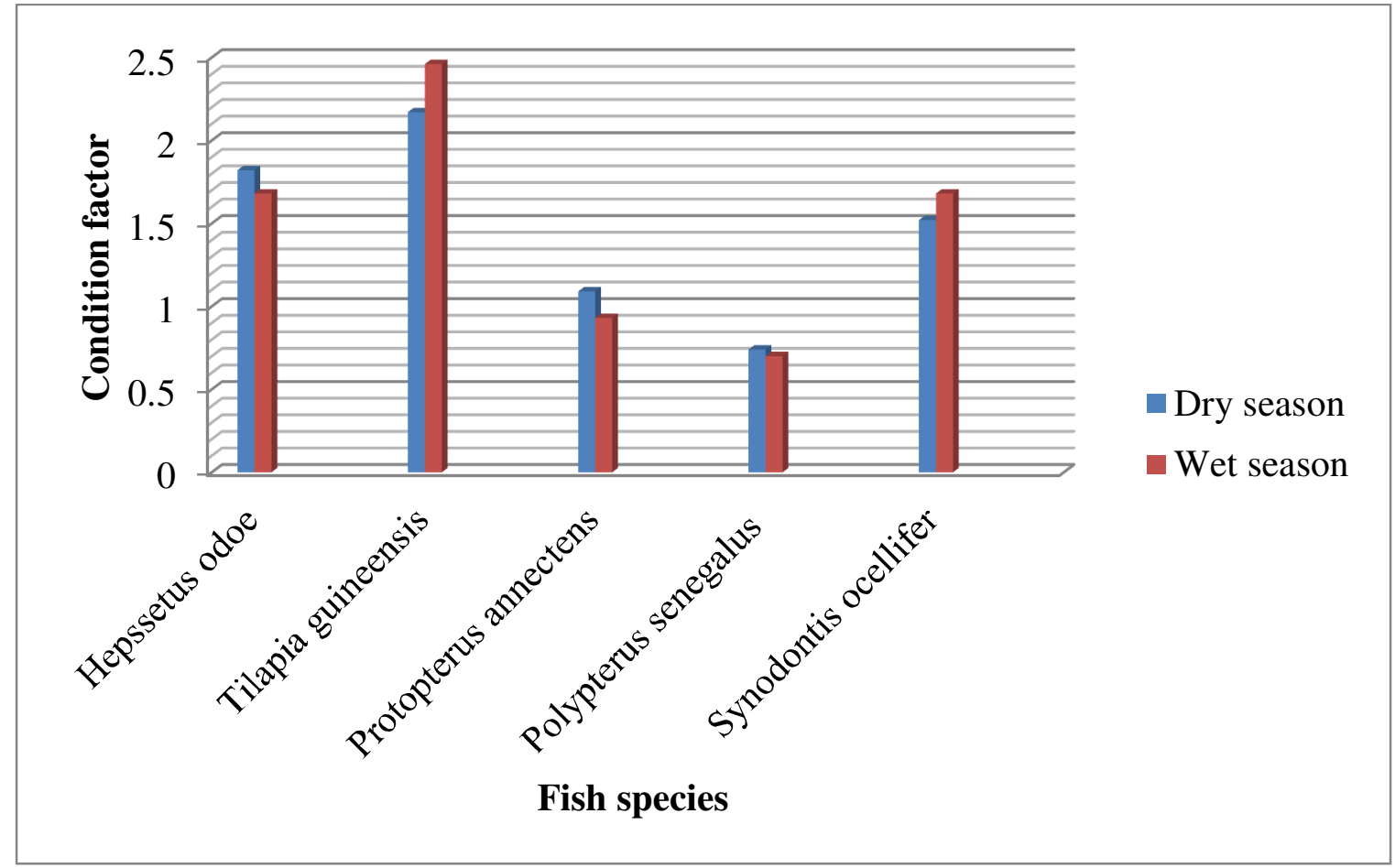

Figure 1: Condition factor of some selected fish species from Kolo creek, Niger Delta

\subsection{CONCLUSION}

In conclusion the length-weight relationship and condition factor give an insight of conditions of a fish in its environment. This study assessed seasonal variation in five important fish species from Kolo creek. The study found that most fish species exhibited negative allometric growth condition apart from Tilapia guineensis which exhibit positive allometric growth pattern during the wet season. Hepssetus odoe, Tilapia guineensis and Synodontis ocellifer had condition factor greater than 1 , while Polypterus senegalus senegalus has condition factor $<1$. The length-weigh relationship suggests the fish species could be affected by anthropogenic activities in the area.

\section{REFERENCES}

Abowei, J. F. N (2009), The Abundance Condition Factor and Length-Weight Relationship of Some Sardinellamaderensis (Jenyms, 1842) from Nkoro 
River, Niger Delta, Nigeria, Advanced Journal of Food Science and Technology, 1(1):65-70

Abowei, J.F.N. (2006). The condition factor lengthweight relationship and abundance of Ilishaafricana( Block 1995) from Nkoro River, Niger Delta, Nigeria. Advanced journal of Food Science and Technology, 2(1):6-11.

Abowei, J.F.N. (2010). The Condition Factor, Length Weight Relationship and Abundance of Ilisha africana (Block, 1795) from Nkoro River Niger Delta, Nigeria. Advance Journal of Food Science and Technology, 2(1): 6-11.

Abu, O.M.G and Agarin, O.J. (2016). Length-Weight Relationship and Condition Factor of Silver Catfish (Chrysichthys nigrodigitatus) from the Lower Reaches of the New Calabar River Niger Delta. International Journal of Innovative Studies in Aquatic Biology and Fisheries, 2(4): 1-7.

Aghoghovwia, O. A. and Ohimain, E. I. (2014). Physicochemical characteristics of lower Kolo creek, Otuogidi, Bayelsa state. Nigerian Journal of Agriculture, Food and Environment, 10(1):23 - 26.

Akombo, P.M., Akange, E.T., Adikwu, I.A. and Araoye, P.A. (2014). Length-weight relationship, condition factor and feeding habits of Synodontis schall (Bloch and Schneider, 1801) In river Benue at Makurdi, Nigeria. International Journal of Fisheries and Aquatic Studies, 1(3): 42-48.

Amiye, F. and Erondu, E.S. (2010). Fish Mortalities and Management Measures of Fish Species of the Andoni River, Niger Delta, Nigeria. Research Journal of Biological Sciences, 5(2) : 171-176,

Angaye, TCN., Cosboy, ME, Zige, DV, Angaye, SS, Izah SC (2015). Assessment of untreated groundwater against some common fresh water Fish in Bayelsa State, Nigeria. Point Journal of Agriculture and Biotechnology Research, 1(2):70 - 76.

Atama, C.I., Okeke, O.C., Ekeh, F.N., Ezenwaji, N.E., Onah, I.E., Ivoke, N., Onoja, U.S. and Eyo, J.E. (2013.) Length-Weight Relationship and Condition Factor of Six Cichlid (Cichilidae: Perciformis) Species of Anambra River, Nigeria. Journal of Fisheries and Aquaculture, 4(2): 82-86.

Dan-Kishiya, A. S. (2013). Length-weight relationship and condition factor of five fish species from a tropical water supply reservoir in Abuja, Nigeria. American Journal of Research Communication, 1(9): 175-187.

De Giosa, M., Czerniejewski, P. and Rybczyk, A. (2014). Seasonal Changes in Condition Factor and WeightLength Relationship of Invasive Carassius gibelio (Bloch, 1782) from Leszczynskie Lakeland, Poland. Advances in Zoology. http://dx.doi.org/10.1155/2014/678763

Gayando, F. C. Jr. and Pauly, D. (1997) eds. FAOICLARM Stock Assessment Tools (FiSAT) Reference manual FAO Computerised Information series (Fisheries) No. 8 Rome, FAO, 262p.
Holden, M. and Reed, W. (1972). West African Fresh water fishes. Longmans Limited London 33p.

Ikongbeh, O.A., Ogbe, F.G. and Solomon, S.G. (2013). Length-Weight Relationship and Condition Factor of Auchenoglanis occidentalis (VALENCIENNES, 1775) from Lake Akata, Benue State, Nigeria. IOSR Journal of Agriculture and Veterinary Science, $3(6): 11-17$.

Inengite AK, Oforka NC, Osuji LC (2010). Evaluation of Polycyclic Aromatic Hydrocarbons in Sediment of Kolo Creek in the Niger Delta, Int. J. App. Env. Sci., 5(1): 127-143.

Inengite AK, Oforka NC, Osuji LC (2012). Sources of Polycyclic Aromatic Hydrocarbons in an Environment Urbanised by Crude Oil Exploration, Environ and Nat Resource Research 2(3): 62-70.

Ineyougha, E.R., Orutugu, L.A. and Izah, S.C. (2015). Assessment of Microbial Quality of Smoked Trachurus trachurus sold in some Markets of Three South-South States of Nigeria. Inter. J. Food Res., 2: $16-23$.

Izah, S.C. and Angaye, T.C.N. (2015). Ecological perception of fish farmers in Yenagoa Metropolis, Nigeria. Bulletin of Advanced Scientific Research, 1(1): $26-28$.

Izah, S.C. and Angaye, T.C.N. (2016). Heavy metal concentration in fishes from surface water in Nigeria: Potential sources of pollutants and mitigation measures. Sky Journal of Biochemistry Research, 5(4): 31-47.

Jan, M. and Ahmed, I. (2016). Length weight relationship and condition factor of snow trout, Schizothorax plagiostomus (Heckel, 1838) from Lidder River, Kashmir. International Journal of Fisheries and Aquatic Studies, 4(2): 131-136

Jiri, C. (1976). A colour guide of familiar fresh water fishes. Octopus Books Ltd. London 25p.

Keyombe, J.L., Waithaka, E. and Obegi, B. (2015). Length-weight relationship and condition factor of Clarias gariepinus in Lake Naivasha, Kenya. International Journal of Fisheries and Aquatic Studies, 2(6): 382-385.

Kouamé K.A., Kamelan, T.M., Nobah, C.S.K., Goore, B.G.. and Kouamélan, E.P. (2016). Length-Weight Relationship and Condition Factor of Synodontis koensis Pellegrin, 1939 in Sassandra River, Côte d'Ivoire. Journal of Environmental Science, Computer Science and Engineering \& Technology, 5(2): 49-58

Kumolu-Johnson, C.A. and Ndimele, P.E. (2010). Length-Weight Relationships and Condition Factors of Twenty-One Fish Species in Ologe Lagoon, Lagos, Nigeria. Asian Journal of Agricultural Sciences, 2(4): 174-179

Lalrinsanga, P.L., Pillai, B.R., Patra, G., Mohanty, S., Naik, N.K. and Sahu, S. (2012). Length Weight Relationship and Condition Factor of Giant Freshwater Prawn Macrobrachium rosenbergii (De Man, 1879) Based on Developmental Stages, 
Culture Stages and Sex. Turkish Journal of Fisheries and Aquatic Sciences, 12: 917-924.

Loveque, C., Pyugy, O. and Teugels, G. G ed (1991). The fresh and brackish water fishes of WestAfrica. Vol. 1 Musee Royale de. 1 Afrique Centrale. Tervurem, Belgique, Editions de IORSTOM: $384 \mathrm{p}$.

Mahmood, K., Ayub, Z., Maazzam, M. and Siddiqui, G. (2012). Length-weight relationship and condition factor of llesha melastoma (Clupeiformes pristigasteridae) off Pakistan. Pakistan Journal of Zoology, 44(1): $71-77$.

Nazeef S. and Abubakar U. M. (2013). Diversity and Condition Factor of Fish Species of Dadin Kowa Dam, Gombe State, Nigeria. Greener Journal of Biological Sciences, 3 (10): 350-356.

Nehemia, A., Maganira, J.D. and Rumisha, C. (2012). Length-Weight relationship and condition factor of tilapia species grown in marine and fresh water ponds. Agriculture and Biology Journal of North America, 3(3): 117-124.

Ogamba, E.N., Izah, S.C. and Toikumo, B.P. (2015). Water quality and levels of lead and mercury in Eichhornia crassipes from a tidal creek receiving abattoir effluent, in the Niger Delta, Nigeria. Continental Journal of Environmental Science, 9(1): $13-25$.

Ogamba. E.N., Abowei, J.F.N. and Onugu, A. (2014). Length-weight relationship and condition factor of selected finfish species from Odi River, Niger Delta, Nigeria. Journal of Aquatic Science, 29(1A):1-12

Onimisi, M.M. and Ogbe, F. G. (2015). Length-Weight Relationships And Condition Factor For Fish Species Of River Okura, Kogi State, Central Nigeria. International Journal of Scientific Research and Engineering Studies, 2 (7): 1-3.

Oribhabor, B. J, Ogbeibu, A. E and Udo, M. T. (2011). The Length-Weight Relationship of Brackish Water/Marine Fish Species Assemblage In Niger Delta Mangrove Creek, Nigeria. Current Research Journal of Biological Science, 3(6): 616-621.

Otobo, A.J.T. (1981) Identification of fish species in a stretch of River Nun. HND Project Rivers State University of Science \& Technology, Port Harcourt.
Pauly, D. (1983). Some simple methods for the assessment of tropical fish stock FAO Fish Tech. paper No. 234. 52p.

Poll, M. (1974): Synopsis and Geographical Distribution of the clupeidea in Africa Firewater. Distribution of three New species. Bull. De Ca Class Des Sci: 5 Sere Tom LX (2) 141- 161.

Raufu, M.O., Adepoju, A.A., Salau A.S. and Adebiyi, A.O. (2009). Determinants of yield performance in small scale fish farming in Alimosho local government area of Lagos state. Int. J. Agric. Econ. Rural Dev. 2(1): 9 - 14.

Reed, W., Burchard, J., Jennes, J. and Yaro I., (1967). Fish and fisheries of Northern Nigeria MOA 226pp. [AQF] [FISR].

Reid, G.M. and Sydenham, H. (1978). A check list of lower Benue River Fishes and on ichtho geographical review of the Benue River. J. Nat. Hist., 13(1) 41-67.

Seiyaboh, E.I., Harry, G.A. and Izah, S.C. (2016a). Length-Weight Relationship and Condition Factor of Five Fish Species from River Brass, Niger Delta. Biotechnological Research,2(4):187-192

Seiyaboh, E.I., Izah, S.C. and Gijo, AH. (2016b). LengthWeight Relationship and Condition Factor of some Important Fish Species from Sangana River, Niger Delta. International Journal of Innovative Agriculture \& Biology Research, 4(4):37-44.

Seiyaboh, E.I., Ogamba, E.N., Utibe, D.I. and Sikoki, F.D. (2013). Impact of Dredging on the Fisheries of Igbedi Creek, Upper Nun River, Niger Delta, Nigeria. IOSR Journal of Environmental Science, Toxicology And Food Technology, 7 (5):38 - 44.

Whitehead, P.J.P. (1984). Family clupeidae Daget, J. Gosse, J. P. Thys. Van den. Audennerede, D. F. S (eds). Checklist of the freshwater fishes of Africa vol. 1 ORSTOM: 11-20.

Whyte, S.A. (1975) Distribution, trophic relationship and breeding habits of the fish population in a tropic lake basin. Lake Busumtwi, Ghana. J. Zool. Lond. 177:25-56. 